\title{
Nutritional Status and School Achievements in a Rural Area of Anti-Atlas, Morocco
}

\author{
Mohamed El Hioui, Fatima-Zahra Azzaoui, Ahmed Omar Touhami Ahami, Youssef Aboussaleh
}

Unit of Clinic and Cognitive Neuroscience and nutritional Health, Laboratory of Biology and Health, Department of Biology, Faculty of Science, Ibn Tofail University, Kenitra, Morocco.

Email: elhioui2000@yahoo.fr

Received May 21 $1^{\text {st }}, 2011$; revised August $4^{\text {th }}, 2011$; accepted August $11^{\text {th }}, 2011$.

\begin{abstract}
Nutritional status is the best indicator of the global well-being of children. However, malnutrition affects physical growth, cognitive development, physical work capacity, and it consequently influences human performance and health. The present study was designed to identify factors that may influence the nutritional status and educational achievements of the children in a rural area of ANTI Atlas of Morocco. The nutritional status of 162 children (12 to 15 years of age) was assessed by nutritional anthropometry and compared with tables of weight-for-age and height-for-age z-scores (WAZ and HAZ) identifying wasting and stunting, respectively. A questionnaire was developed to collect information about socio-economic and demographic status of the children's families. Also, educational achievements were assessed by their score in mathematics. A total of 162 children (64 boys and 98 girls), aged 12 - 15 years. Results revealed $22.8 \%$ of stunting and $35.2 \%$ of wasting. Child age $(p=0.027)$, illiteracy of the mother $(p=0.004)$ was determinant factors with wasting. Stunting was significantly associated with gender $(p=0.03)$ and parents' employment $(p=0.009)$. However, using logistic regression analysis, the results showed that stunting $(p=0.04)$ and mother level of education $(p=0.032)$ were significantly correlated with school achievements. In this area of study, malnutrition remains a major problem among adolescents' school performances, which can affect their future. The main causes of malnutrition seem to be the bad weaning practices among school children and cultural attitudes of food. The educational achievements of school children are influenced by maternal education and stunting.
\end{abstract}

Keywords: Nutritional Status, Undernutrition, School Achievements and Morocco

\section{Introduction}

Child malnourishment remains a leading public health concern in developing countries. According to data from the Food and Agriculture Organization [1], every day 799 million people in developing countries - about 14\% of the world's population go hungry. Approximately 175 million children under 5 years of age are estimated to be underweight, $32 \%$ of preschool children are stunted, $16 \%$ of birth weights are below $2.5 \mathrm{~kg}$, and 243 million adults are severely malnourished. The deficiency in nutritional status of a child is the result of macronutrient (calories and protein) and micronutrient (vitamins, iodine, and iron) deficiencies from inadequate food consumption or from illnesses such as diarrhea [2]. It is quantified using the anthropometric indices of height for age, weight for age, and weight for height; all are expressed as a Z-score, which compare a child's measurements with the measurements of a similar child in a reference, healthy population [3]. A low height for age Z-score (stunting) indicates slow physical growth since the birth, usually due to repeated episodes of poor nutrition and/or episodes of diarrhea and other illnesses. It is a cumulative indicator of past episodes of malnutrition, often thought of as stock measure of malnutrition. A low weight for height $Z$-score (wasting) indicates current malnutrition and/or recent episodes of diarrhea and other illnesses, often thought of as a flow measure of malnutrition. A low weight for age Z-score (underweight) reflects both stunting and wasting [4].

The conceptual framework of causes of malnutrition was developed in 1998 as part of UNICEF Nutrition Strategy. It draws attention not just to the immediate causes such as inadequate food and nutrients and frequent illness, but also to how these in turn are related to access to food through household food security, the environment in which people live, and the caring practices performed.

Consequences of malnourishment include increased risk of morbidity and mortality from infectious diseases [5], impaired cognitive or behavioral development in 
short or long term [6,7] and reduced educational and productive capacity in adulthood [8].

The present study was designed to identify factors that may influence stunting and wasting and relationship between nutritional status and educational achievements of the children in a rural area of ANTI Atlas region of Morocco.

\section{Materials and Methods}

\subsection{Study Area}

This study was conducted in Bir Anzaran college (middle school), located in Ifran Anti-Atlas village (Wilayah of Guelmim-Smara in the South of Morocco). This village is $222 \mathrm{~km}$ to the southeast of Agadir, the capital of Souss. It is known as one of the most food-insecure areas in the country. Its topography varies from mountainous to hilly areas.

\subsection{Sample}

One hundred sixty-two children (64 boys and 98 girls) aged 12 to 15 years were included in this study. The majority of children lives in Ifran village, but some others need to walk over an $8 \mathrm{Km}$ to reach the college. The village is supplied with drinking water and electricity and has septic tanks for sanitation.

\subsection{Data Collection}

The cross-sectional survey was conducted using a questionnaire structured into several themes.

Demographic and anthropometric indicators: age, sex, weight, height. The methods of measuring and the assessment of weight and height accuracy's measurements were carried out according the guidelines described by Cogill (2003) [9].

The indicators of malnutrition (height for age and weight for age were determined by Z-scores and calcu- lated with the software Epi info 2000). Stunting and wasting were defined as height-for-age and weight-for-age $\mathrm{Z}<-2$ respectively $[10,11]$.

Socio-economic data: the family's income, the parents' educational status, the number of family members.

Indeed, the educational achievements were assessed by the students' score in mathematics. In the other side the academic performances were assessed every trimester and the score given was the average one.

\subsection{Statistical Analysis}

Chi-2 test and the logistic regression analysis were used to investigate the relationship between the prevalence of malnutrition and the sociodemographic factors and school achievement. Differences were considered statistically significant at a $\mathrm{p}<0.05$.

\section{Results}

The average age of participants was $13.67 \pm 0.97$ years.
Eighty four percent $(\mathrm{n}=136)$ were aged under 13 years and $16 \%(\mathrm{n}=26)$ aged 13 years and over. The majority of mothers had an irregular income $79.6 \%$, but the majority of fathers $84.6 \%$ had a regular income. Only $29.6 \%$ of the mothers and $13.6 \%$ of fathers had a secondary level of education ( $\geq 5$ years). Also, the families with low education level had an important number of family members (Table 1).

According to the anthropometric data, 37 cases $(22.8 \%)$ were stunted, 57 cases $(35.2 \%)$ were wasted. Stunting was significantly associated with sex $(\mathrm{p}<0.05)$ and mother's income $(p<0.05)$ (Table 1) and it was confirmed by logistic regression analysis (Table 2). However, there was no significant relationship between wasting and $\operatorname{sex}(\mathrm{p}>0.05)$ (Table 3).

Significant relationship was noted between Wasting and Mother's education level $(\mathrm{p}=0.004)$ (Table 3$)$ and it was confirmed by logistic regression analysis (Table 4).

Table 5 provides an overview of the associations between the nutritional, socioeconomic parameters and the indicators of cognitive performance. The logistic regression was used to identify the factors influencing children's school achievements. Stunting and mother's education level were significantly related to school achievement. The overall F-ratio for all variables was $2.65(\mathrm{df}=6)$ and was highly significant $(\mathrm{p}=0.019)$.

\section{Discussion}

Malnutrition is one of the greatest problems facing developing countries, including rural regions of Morocco, in terms of wasting and stunting among school children. However, a little information was registered about the prevalence of stunting and wasting among school children in Morocco and especially in Anti-Atlas region.

In this study, the prevalence of stunting was $22.8 \%$ and the prevalence of wasting (35.2\%) was more serious. Also, the malnutrition was significantly more frequent among boys than girls. This finding was in accordance with several studies which showed that undernutrition among boys was more serious than that among girls according to all three indicators; stunting, wasting and underweight [12], and it worsens among boys with age [13].

In previous study of our equip, realized in Gharb plain (Coastal Area of Morocco), the prevalence of stunting and wasting among rural school aged children were $8.9 \%$ and $12.6 \%$ respectively [14]; the values were lower than finding in this region.

The literacy of the mother appears as a risk factor more important in this study. Wasting size increases significantly with low level of mother education's ( $p=$ 0.004). However, no significant relationship between stunting and wasting and number of family members was registered among school aged children in Gharb plain 
Table 1. Prevalence of stunting and sociodemographic factors.

\begin{tabular}{|c|c|c|c|c|c|c|c|}
\hline & \multicolumn{2}{|c|}{ All the cases } & \multicolumn{2}{|c|}{ S. cases } & \multirow[t]{2}{*}{ OR } & \multirow[t]{2}{*}{$95 \% \mathrm{CI}$} & \multirow[t]{2}{*}{ p-value } \\
\hline & $\mathrm{N}$ & $\%$ & $\mathrm{~N}$ & $\%$ & & & \\
\hline \multicolumn{8}{|l|}{ Sex } \\
\hline M & 64 & 59.5 & 28 & 75.7 & \multirow{2}{*}{0.409} & 0.178 & \multirow{2}{*}{0.032} \\
\hline $\mathrm{F}$ & 98 & 60.5 & 9 & 24.3 & & 0.938 & \\
\hline \multicolumn{8}{|c|}{ Age (years) } \\
\hline$<13 \mathrm{yr}$. & 136 & 83.9 & 29 & 17.9 & \multirow{2}{*}{1.64} & 0.648 & \multirow{2}{*}{0.29} \\
\hline$\geq 13 \mathrm{yr}$. & 26 & 16.1 & 8 & 82.1 & & 4.150 & \\
\hline \multicolumn{8}{|c|}{ Moths. Inc } \\
\hline Reg. & 33 & 20.4 & 3 & 8.1 & \multirow{2}{*}{0.279} & 0.080 & \multirow{2}{*}{0.037} \\
\hline Irreg. & 129 & 79.6 & 34 & 91.9 & & 0.975 & \\
\hline \multicolumn{8}{|c|}{ Faths. inc. } \\
\hline Reg. & 137 & 84.6 & 33 & 89.2 & \multirow{2}{*}{1.211} & 0.379 & \multirow{2}{*}{0.747} \\
\hline Irreg. & 25 & 15.4 & 4 & 10.8 & & 3.874 & \\
\hline \multicolumn{8}{|c|}{ Moths. educ. lvl. } \\
\hline$<5 \mathrm{yr}$ & 114 & 70.4 & 26 & 70.3 & \multirow{2}{*}{1.006} & 0.459 & \multirow{2}{*}{0.988} \\
\hline$\geq 5 \mathrm{yr}$ & 48 & 29.6 & 11 & 29.7 & & 2.246 & \\
\hline \multicolumn{8}{|c|}{ Faths. educ. lvl. } \\
\hline$<5 \mathrm{yr}$ & 140 & 86.4 & 32 & 19.7 & \multirow[b]{2}{*}{0.993} & 0.340 & \multirow[b]{2}{*}{0.989} \\
\hline$\geq 5 \mathrm{yr}$ & 22 & 13.6 & 5 & 80.3 & & 2.901 & \\
\hline \multicolumn{8}{|c|}{ Nb. of FM. } \\
\hline$<5$ & 65 & 40.1 & 16 & 43.2 & \multirow[b]{2}{*}{0.409} & 0.178 & \multirow[b]{2}{*}{0.875} \\
\hline$\geq 5$ & 97 & 59.9 & 21 & 56.8 & & 0.938 & \\
\hline
\end{tabular}

S. cases: Stunted cases; Moths. inc.; Mother's income; Reg.: regular; Irreg: irregular; Faths inc: Father's income; Moths. educ. lvl.: Mother's education level; Faths. educ. lvl.: Father's education level; Nb. of FM: Number of family members. CI = confidence interval; $p$ values $<0.05$ were considered significant and represented in bold.

Table 2. Logistic regression test results of stunting and sociodemographic factors ${ }^{\mathrm{a}}$.

\begin{tabular}{|c|c|c|c|c|c|c|c|c|}
\hline & \multirow{2}{*}{ B } & \multirow{2}{*}{ ES } & \multirow{2}{*}{ Wald } & \multirow{2}{*}{$\mathrm{df}$} & \multirow{2}{*}{ Sig } & \multirow{2}{*}{$\mathrm{OR}^{\mathrm{b}}$} & \multicolumn{2}{|c|}{$95 \% \mathrm{CI}$} \\
\hline & & & & & & & Lower & Upper \\
\hline Sex & 0.907 & 0.430 & 4.460 & 1 & 0.035 & 2.477 & 1.067 & 5.748 \\
\hline Moths. educ. lvl. & -0.015 & 0.422 & 0.001 & 1 & 0.971 & 0.985 & 0.430 & 2.254 \\
\hline Faths inc. & 0.094 & 0.206 & 0.209 & 1 & 0.647 & 1.099 & 0.734 & 1.647 \\
\hline Moths. inc. & 1.329 & 0.646 & 4.230 & 1 & 0.040 & 3.776 & 1.065 & 13.396 \\
\hline
\end{tabular}

Moths. educ. 1vl.: Mother's education level; Faths inc.: Father's income;Moths. inc.; Mother's income; ${ }^{\mathrm{a}}$ Results with $\mathrm{p}<0.2$ were included in the logistic regression univariate analysis; ${ }^{\mathrm{b}}$ Adjusted odds ratio; $\mathrm{p}$ values $<0.05$ were considered significant and represented in bold. 
Table 3. Prevalence of wasting and sociodemographic factors.

\begin{tabular}{|c|c|c|c|c|c|c|c|}
\hline & \multicolumn{2}{|c|}{ All The cases } & \multicolumn{2}{|c|}{ W. cases } & \multirow[t]{2}{*}{ OR } & \multirow[t]{2}{*}{$95 \% \mathrm{CI}$} & \multirow[t]{2}{*}{$\mathrm{p}$-value } \\
\hline & $\mathrm{N}$ & $\%$ & $\mathrm{~N}$ & $\%$ & & & \\
\hline \multicolumn{8}{|l|}{ Sex } \\
\hline M & 64 & 39.5 & 37 & 64.9 & \multirow[b]{2}{*}{0.749} & 0.384 & \\
\hline $\mathrm{F}$ & 98 & 60.5 & 20 & 35.1 & & 1.461 & 0.397 \\
\hline \multicolumn{8}{|c|}{ Age (years) } \\
\hline$<13 \mathrm{yrs}$ & 136 & 84 & 46 & 80.7 & \multirow[b]{2}{*}{1.435} & 0.610 & \multirow[b]{2}{*}{0.407} \\
\hline$\geq 13 \mathrm{yrs}$ & 26 & 16 & 11 & 19.3 & & 3.375 & \\
\hline \multicolumn{8}{|c|}{ Moths. inc. } \\
\hline Reg. & 33 & 20.4 & 11 & 19.3 & \multirow[b]{2}{*}{1.256} & 0.571 & \multirow[b]{2}{*}{0.570} \\
\hline Irreg. & 129 & 79.6 & 46 & 80.7 & & 2.760 & \\
\hline \multicolumn{8}{|c|}{ Faths inc. } \\
\hline Reg. & 142 & 86.6 & 50 & 87.7 & \multirow[b]{2}{*}{1.009} & 0.378 & \multirow[b]{2}{*}{0.985} \\
\hline Irreg. & 20 & 13.4 & 7 & 12.3 & & 2.693 & \\
\hline \multicolumn{8}{|c|}{ Moths. educ. lvl. } \\
\hline$<5$ yrs. & 114 & 70.4 & 48 & 84.2 & \multirow[b]{2}{*}{0.314} & 0.141 & \multirow[b]{2}{*}{0.004} \\
\hline$\geq 5 \mathrm{yrs}$ & 48 & 29.6 & 9 & 15.8 & & 717 & \\
\hline \multicolumn{8}{|c|}{ Faths. educ. Ivl. } \\
\hline$<5$ yrs. & 140 & 86.4 & 49 & 85.9 & \multirow{2}{*}{1.061} & 0.416 & \multirow{2}{*}{0.901} \\
\hline$\geq 5 \mathrm{yrs}$ & 22 & 13.6 & 8 & 14.1 & & 2.705 & \\
\hline \multicolumn{8}{|c|}{ Nb. of FM. } \\
\hline$<5$ & 65 & 40.1 & 18 & 31.6 & \multirow[b]{2}{*}{0.749} & 0.384 & \multirow[b]{2}{*}{0.397} \\
\hline$\geq 5$ & 97 & 59.8 & 39 & 68.4 & & 1.461 & \\
\hline
\end{tabular}

W. cases: Wasted cases; Moths. inc.; Mother's income; Reg.: regular; Irreg: irregular; Faths inc.: Father's income; Moths. educ. lvl.: Mother's education level; Faths. educ. lvl.: Father's education level; Nb. of FM.: Number of family members; CI = confidence interval; $p$ value $<0.05$ were considered significant and represented in bold.

Table 4. Logistic regression test results of wasting and sociodemographic factors ${ }^{\mathrm{a}}$.

\begin{tabular}{|c|c|c|c|c|c|c|c|c|}
\hline & \multirow[b]{2}{*}{ B } & \multirow[b]{2}{*}{ ES } & \multirow[b]{2}{*}{ Wald } & \multirow[b]{2}{*}{ df } & \multirow[b]{2}{*}{ Sig } & \multirow{2}{*}{$\mathrm{OR}^{\mathrm{b}}$} & \multicolumn{2}{|c|}{$95 \% \mathrm{CI}$} \\
\hline & & & & & & & Lower & Upper \\
\hline Constant & -0.829 & 0.530 & 2.451 & 1 & 0.117 & & & \\
\hline Moths. educ. Ivl. & 1.148 & 0.416 & 7.628 & 1 & 0.006 & 3.152 & 1.396 & 7.117 \\
\hline
\end{tabular}

Moths. educ. lvl.: Mother's education level; ${ }^{a}$ Results with $\mathrm{p}<0.2$ were included in the logistic regression univariate analysis; ${ }^{\mathrm{b}}$ Adjusted odds ratio; $\mathrm{p}$ values $<0.05$ were considered significant and represented in bold. 
Table 5. Overview of associations of nutritional and socioeconomic factors with scholar performance.

\begin{tabular}{lccccccc}
\hline & $\mathrm{B}$ & $\mathrm{SE}$ & $\mathrm{Bêta}$ & $\mathrm{t}$ & $\mathrm{p}$ & \multicolumn{2}{c}{$95 \%$ CI for B } \\
\hline H/A zsc. & 2.004 & 1.009 & 0.187 & 1.986 & $\mathbf{0 . 0 4 9}$ & 4.002 & 0.007 \\
W/A zsc. & 0.122 & 0.903 & 0.013 & 0.135 & 0.892 & 1.910 & 1.665 \\
Nb. of FM & 0.028 & 0.173 & 0.014 & 0.160 & 0.873 & 0.315 & 0.370 \\
Faths. educ. Lvl. & 0.965 & 0.619 & 0.137 & 1.560 & 0.121 & 0.260 & 2.190 \\
Moths. educ. lvl. & 1.862 & 0.859 & 0.197 & 2.167 & $\mathbf{0 . 0 3 2}$ & 0.161 & 3.562 \\
Faths. Inc. & 0.430 & 0.406 & 0.092 & 1.058 & 0.292 & 0.374 & 1.233 \\
\hline
\end{tabular}

H/A zsc.: Height-for-age z-score; W/A zsc.: Weight-for-age z-score; Nb. of FM: Number of family members, Faths. educ. lvl.: Father's education level; Moths. educ. lvl.: Mother's education level; Faths. inc.: Father's income; B = Ordinary least-squares regression: SE B standard error of B, Beta = standard Beta coefficient: $C I=$ confidence interval Model Summary: $R=0.34 ; R^{2}=0.11$; adjusted $R^{2}=0.71 ;$ F-ratio $=2.65(d f=6) ; p=0.019$.

(NW of Morocco) [15]. Nevertheless, some studies showed that the prevalence of stunting, underweight in children was associated with number of persons in the house [16], [17] and demonstrated also, that children from a low socio-economic environment had had significantly higher percentages of undernutrition [18].

The obtained results of wasting and stunting could be explained by the children diet's in this region which is poor and based on wheat or some traditional preparations of wheat seeds. Unfortunately, the wheat wasn't whole in several times. The consumption of vegetables and fruits are frequent, but meat isn't it.

In addition, stunting was found significantly positively related to school achievements $(p=0.049)$. In agreement with our findings, lower z-points of height for age reflecting longer term undernutrition, and had being associated with poorer cognitive performance in younger (1 - 3 years) $[19,20]$ and school children [21,22]. Moreover, some studies have demonstrated that protein-energy supplementation, in young children, is beneficial for the long term cognitive development [23-25].

It was shown in this study that the parents' education is positively correlated to children school achievements (mathematics scores). This result demonstrates the important impact of family environment on the performance of the child to school. Our results are consistent with others which found that the child family characteristics' have a decisive influence on its performance at school. In particular, they stressed like other authors that parents encourage the return of their children if they have a high level of education [26]. In another survey carried out among school children aged 6 to 16 years in the city of Kenitra (Morocco), it was noted that the educational level of parents had a significant impact on school performances of children, and on their absenteeism [27]. Indeed, it has reported that the genetic and environmental factors like socio-economic, socio-cultural and psychological factors could be direct or indirect co-determinants of both intelligence and school performances [28].

\section{Conclusions}

Malnutrition remains a major problem among school children. Parents' Level education and stunting were determinant factors in this health problem. The consequences are more threatening when it harms in school achievements of children. More investigations are necessary to study all the possible influence of other factors, due to multifactorial approach of this health problem.

\section{Acknowledgements}

The authors are very grateful to the children, their parents, the staff of the Bir-Anzaran High School and to the staff of Ifran Hospital for their considerable help and contributions to this research.

\section{REFERENCES}

[1] Food and Agriculture Organization FAO, "The State of Food Insecurity in the World 2003: Monitoring Progress towards the World Food Summit and Millennium Development Goals," Food and Agriculture Organization, Rome, 2003.

[2] J. R. Behrman, H. Alderman and J. Hoddinott, "Hunger and Malnutrition," In: B. Lomborg, Ed., Global Crisis, Global Solutions, Cambridge University Press, Cambridge, 2004. doi:10.1017/CBO9780511492624.008

[3] R. Martorell, "Child Growth Retardation: A Discussion of Its Causes and Its Relationship to Health," In: K. Blaxter, and J. C. Waterlow, Eds., Nutritional Adaptation in Man, John Libby, London, 1985.

[4] S. L. W. Wisniewski, "Child Nutrition, Health Problems, and School Achievement in Sri Lanka," World Development, Vol. 38, No. 3, 2010, pp. 315-332. doi:10.1016/j.worlddev.2009.09.009

[5] S. Moore, A. Collinson, P. N'gom, R. Aspinall and A. Prentice, "Early Immunological Development and Mortality from Infectious Disease in Later Life," Proceedings of the Nutrition Society, Vol. 65, No. 3, 2006, pp. 311-318. doi:10.1079/PNS2006503 
[6] S. McGregor, Y. Cheung, S. Cueto, P. Glewwe, L. Richter and L. Strupp, "Developmental Potential in the First 5 Years for Children in Developing Countries," Lancet, Vol. 369, No. 9555, 2007, pp. 60-70. doi:10.1016/S0140-6736(07)60032-4

[7] E. Pollitt, "Malnutrition and Infection in the Classroom: Summary and Conclusions," Food and Nutrition Bulletin, Vol. 12, No. 3, 1990.

[8] C. Victora, L. Adair, C. Fall, P. Hallal, R. Martorell, L. Richter, et al., "Maternal and Child Undernutrition: Consequences for Adult Health and Human Capital," Lancet, Vol. 371, No. 9609, 2008, pp. 340-357. doi:10.1016/S0140-6736(07)61692-4

[9] B. Cogill, "Anthropometric Indicators Measurement Guide," Food and Nutrition Technical Assistance Project, Academy for Educational Development, Washington, D.C, 2003.

[10] United Nations Children's Fund (UNICEF), "How to Weigh and Measure Children: Assessing the Nutritional Status of Young Children in Household Surveys," United Nations Department of Technical Co-operation for Development and Statistical Office (UNICEF), New York: 1986.

[11] World Health Organization (WHO), "Measuring Change in Nutritional Status. Guidelines for Assessing the $\mathrm{Nu}-$ tritional Impact of Supplementary Feeding Programmes for Vulnerable Groups," WHO, Geneva, 1983.

[12] E. S. Tee, S. C. Khor, H. E. Ooi, et al., "Regional Study of Nutritional Status of Urban Primary School Children. 3. Kuala Lumpur Malaysia," Food and Nutrition Bulletin, Vol. 23, 2002, pp. 41-47.

[13] I. M. Parraga, A. M. Assis, M. S. Prado, et al., "Gender Differences in Growth of School-Age Children with Schistosomiasis and Geohelminth Infection," American Journal of Tropical Medicine and Hygiene, Vol. 55, 1996, pp. 150-156.

[14] M. El Hioui, A., Ahami, Y. Aboussaleh and S. Rusinek, "Stunting and Wasting of Schoolchildren in Rural Morocco," Bulletin de la Société de Pharmacie de Bordeaux, Vol. 147, 2008, pp. 61-70.

[15] F.-Z. Azzaoui, A. O. T Ahami and A. Khadmaoui, "Relation Entre les Facteurs Socio-Economiques, Environnementaux et la Malnutrition: Cas d'enfants Agés de 6 à 8 ans de la Plaine du Gharb (Nord-Ouest Marocain), Antropo, Vol. 17, 2008, pp. 1-5.

[16] L. V. Guimaraes, M. D. Latorre and M. D. Barros, "Risk Factors in the Occurrence of Short Stature of Preschool Children," Cadernos de Saúde Pública, Vol. 15, 1999, pp. 605-615.

[17] M. Ulukanligil and A. Seyrek, "Demographic and Socioeconomic Factors Effecting the Physical Development, Hemoglobin and Parasitic Infection Status of School Children in Sanliurfa Province," Turkey JAMA, Vol. 118, 2004, pp. 151-58.

[18] I. Nebigil, S. Hizel and G. Tanyer, "Height and Weights of Primary School Children of Different Social Background in Ankara, Turkey," Journal of Tropical Pediatrics, Vol. 43, No. 5, 1997, pp. 297-303. doi:10.1093/tropej/43.5.297

[19] M. Sigman, C. Neumann, M. Baksh, et al., "Relationship between Nutrition and Development in Kenyan Toddlers," The Journal of Pediatrics, Vol. 115, No. 3, 1989, pp. 357-364. doi:10.1016/S0022-3476(89)80832-7

[20] S. E. Whaley, M. Sigman, M. P. Espinosa, et al., "Infant Predictors of Cognitive Development in an Undernourished Kenyan Population," Journal of Developmental \& Behavioral Pediatrics, Vol. 19, No. 3, 1998, pp. 169-177. doi:10.1097/00004703-199806000-00004

[21] F. E. Johnston, S. M. Low and Y. Baessa, "Interaction of Nutritional and Socioeconomic Status as Determinants of Cognitive Development in Disadvantaged Urban Guatemalan Children," American Journal of Physical Anthropology, Vol. 73, No. 4, 1987, pp. 501-506. doi:10.1002/ajpa.1330730412

[22] C. Powell and S. M. Grantham-McGregor "The Associations between Nutritional Status, School Achievement and School Attendance in Twelve-Year-Old Children at a Jamaican School," West Indian Medical Journal, Vol. 29, No. 4, 1980, pp. 247-53.

[23] S. P. Walker, S. M. Chang and C. A. Powell, "Effects of Early Childhood Psychosocial Stimulation and Nutritional Supplementation on Cognition and Education in Growth Stunted Jamaican Children, Prospective Cohort Study," Lancet, Vol. 366, No. 9499, 2005, pp. 1804-1807. doi:10.1016/S0140-6736(05)67574-5

[24] S. M. Grantham-McGregor and S. P. Walker, "Effects of early Childhood Supplementation with and without Stimulation on Later Development in Stunted Jamaican Children," American Journal of Clinical Nutrition, Vol. 66, No. 2, 1997, pp. 247-253.

[25] E. Pollitt, W. E. Watkins and M. A. Husaini, "ThreeMonth Nutritional Supplementation in Indonesian Infants and Toddlers Benefits Memory Function 8 y Later," American Journal of Clinical Nutrition, Vol. 66, No. 6 , 1997, pp. 1357-1363.

[26] M. Hack, N. Breslau, D. Aram, B. Weissman, N. Klein and E. Borawski-Clark, "The Effect of Very Low Birth Weight and Social Risk on Neurocognitive Abilities at School Age," Journal of Developmental \& Behavioral Pediatrics, Vol. 13, No. 6, 1992, pp. 412-420. doi:10.1097/00004703-199212000-00005

[27] M. El Hioui, A. O. T. Ahami, Y. Aboussaleh, S. Rusinek, K. Dik and A. Soualem, "Aneamia and Neuro-Cognitive Development among Rural School Children in Kenitra, Morocco," Antropo, Vol. 24, 2011, pp. 55-59.

[28] P. A. Vernon, J. C. Wickett, P. G. Bazana and R. M. Stelmack, "The Neuropsychology and Psychophysiology of Human Intelligence. In: R. J. Sterberg, Ed., Handbook of Intelligence, Cambridge University Press, New York, 2000. 